\title{
KESAN PEMBELAJARAN MENERUSI PENGGUNAAN BAHAN BACAAN INTERAKTIF BERASASKAN LAMAN WEB TERHADAP KEFAHAMAN MEMBACA KANAK-KANAK
}

\author{
Learning Effect Through The Use of Website-Based Interactive Reading Materials on \\ Understanding Children Reading
}

\author{
Adenan Ayob \\ Fakulti Bahasa dan Komunikasi, Universiti Pendidikan Sultan Idris, \\ 35900 Tanjong Malim, Perak \\ adenan@fbk.upsi.edu.my
}

\begin{abstract}
ABSTRAK
Perkembangan bidang teknologi dalam sistem pendidikan Bahasa Melayu pada alaf ini sedang mengalami transformasi yang amat pesat. Transformasi dalam bidang ini, terutamanya dalam pengajaran dan pembelajaran Bahasa Melayu dapat dilihat menerusi kewujudan dan penggunaan bahan yang interaktif dengan berasaskan laman web. Dalam mentransformasikan perkembangan tersebut, kajian ini dilakukan untuk mengenal pasti kefahaman membaca kanak-kanak dengan menggunakan bahan bacaan interaktif. Dua kumpulan kajian dikenal pasti dalam kajian ini. Sampel kajian terdiri daripada 60 orang kanak-kanak lapan tahun, masing-masing 30 orang di Perak dan Selangor. Bagi setiap negeri, satu kumpulan telah didedahkan dengan penggunaan bahan bacaan berasaskan laman web. Satu kumpulan yang lain pula telah didedahkan dengan penggunaan bahan konvensional. Data kajian dianalisis secara deskriptif dan inferensi. Data deskriptif ialah min dan sisihan piawai. Data inferensi pula dianalisis dengan menggunakan statistik ANCOVA. Dapatan kajian menunjukkan bahawa terdapat perbezaan yang signifikan antara penggunaan bahan bacaan interaktif berasaskan laman web dengan penggunaan bahan konvensional apabila ujian pra dikawal secara statistik atau dikovariatkan. Dari segi penggunaannya, bahan bacaan berasaskan laman web mampu menjana murid lebih kreatif dan kritis untuk memahami bacaan. Justeru, dicadangkan supaya pihak Kementerian Pendidikan Malaysia dan Pusat PERMATA Negara melaksanakan penggunaan bahan berkenaan secara giat dalam usaha meningkatkan kefahaman membaca kanak-kanak.
\end{abstract}

Kata Kunci: Teknologi dalam sistem pendidikan, bahan bacaan interaktif, laman web, kefahaman membaca.

\begin{abstract}
A great competition in terms of the use of computer based materials and information technology dynamically occurs in the classroom in this era of digital transformation. The use of a variety of technology-based materials is strongly encouraged teaching in order to generate learning that based on effective strategies. In the context of mind assimilation and accommodation, the beginning of teaching that based on various language skills for children should be involved with the exploration of high level knowledge. In achieving that aspiration, this research aims to identify the effect of using interactive web-based reading materials towards student's reading performance. The use of interactive web based is compared to the use of conventional material. The sample involves 60 eight years old primary school children in Perak (30 students) and Selangor (30 students). The descriptive data are mean and standard deviation while the inferential data is ANCOVA statistic. The finding of this study showed that there is a significant difference in the achievement of reading comprehension of children exposed to the use of interactive web-based reading materials compared to the use of conventional materials. The improvement in achievement in terms of reading comprehension suggests that the reading material is suitable for reading in this era of technology. Hence, it is recommended to the Ministry of Education of Malaysia and the PERMATA National Centre to intensify its use in the classroom.
\end{abstract}

Keywords: technology-based materials, interactive web-based reading materials, website, understanding reading 


\section{PENGENALAN}

\section{Latar Belakang kajian}

Teradapat berbagai-bagai pendapat tentang pengertian membaca. Secara amnya, membaca dimaksudkan sebagai penggaraban makna atau memahami kombinasi maklumat atau himpunan gambaran atau pembentukan atau mapping minda daripada bahan bacaan. Membaca juga ialah proses dikaitkan dengan pengalaman dan pengetahuan sedia ada yang dimiliki oleh seseorang pembaca. Justeru, misi akhir membaca adalah untuk memahami apa-apa yang dibaca atau digambarkan atau dibentuk dalam fikiran (Kalhor \& Shakibaei, 2012).

Perkembangan aktif sistem pendidikan pada era ini disinonimkan dengan perubahan yang amat drastik, selain direncanakan secara sistematik dalam pengurusan pendidikan. Senario perubahan dalam sistem pendidikan dapat dikenal pasti daripada kewujudan dan penggunaan bahan yang interaktif berasaskan teknologi. Nickolarazi dan Vekiri (2012) berpendapat bahawa teknologi pengajaran dan pembelajaran ialah penyatuan antara manusia, peralatan, teknik dan peristiwa. Tujuannya untuk memberikan impak yang selari dengan pembentukan keinsanan. Saeedi, Saif, Asadzadah dan Qavam (2013) pula menegaskan bahawa teknologi pengajaran dan pembelajaran ialah cara yang sofistikated ke arah penerokaan ilmu. Ini meliputi kemudahan infrastruktur, pengurusan pedagogi serta persekitaran yang kreatif, kritis dan inovatif.

\section{Pernyataan Masalah}

Jika ditelitikan secara terperinci, aspek kefahaman membaca memang perlukan kemahiran dan kecekapan individu, terutamanya yang berhubung dengan pendidikan awal kanak-kanak. Daripada beberapa kajian tentang kefahaman membaca, faktor utama yang menyumbang adalah seperti keupayaan dalam menaakul maklumat, dan matlamat akhir adalah untuk memahami sesuatu bahan bacaan (Singh \& Mishra, 2013). Faktor memori, tumpuan dan penghayatan terhadap bahan; kemampuan linguistik, keupayaan dalam memahami bahasa pertuturan dan tafsiran perkataan turut menyumbang ke arah kefahaman (Singh \& Mishra, 2016).

Beberapa kajian yang dilakukan telah memaparkan bahawa pengajaran dan pembelajaran membaca dalam kalangan kanak-kanak tidak memberikan tumpuan kepada aspek kefahaman (Singh \& Mishra, 2013). Hal ini demikian kerana bagi guru, elemen yang penting adalah sekadar mahukan kanak-kanak boleh membaca dengan lancar tanpa memahami isi penting. Pendapat tentang permasalahan ini disokong oleh Phantharakphong dan Pothitha (2013), bahawa bahan pengajaran dan pembelajaran yang dianggap konvensional dalam membaca ialah kurikulum pedagogi yang terlalu dominan.

Jika ditinjau daripada prespektif yang terlalu tradisional pula, dapat ditinjau bahawa kesan membaca adalah kurang dinamik terhadap kefahaman yang kanak-kanak peroleh (Heidarifard, 2014), selain berupa kemahiran yang bermula daripada pengenalan huruf dan bunyi, dan diikuti perkataan serta ayat hingga kanak-kanak hanya boleh membaca dengan lancar. Menurut Singh dan Mishra (2016) pula, kefahaman membaca dianggap sebagai aras puncak dalam hierarki pembacaan. Oleh itu, kanak-kanak tidak akan dapat mencapai peringkat tersebut selagi tidak menguasai aras bawah (Singh \& Mishra, 2016). 
Kajian tentang pendidikan membaca secara agak tradisi yang berlaku di peringkat awal pendidikan kanak-kanak pada hari ini masih mengabaikan keupayaan dalam pembentukan integrasi berasaskan bahan yang interaktif. Sebaliknya, fokus adalah kepada lambang dan kemahiran membaca mengikut peringkat-peringkat sahaja (Suleimani \& Nahizadah, 2012). Justeru, kanak-kanak tidak dieksploitasikan dengan penggunaan bahan bacaan yang berasaskan laman web yang banyak manfaatnya terhadap pencapaian kefahaman membaca.

Jelasnya, penggunaan bahan bacaan yang interaktif berasaskan laman web mampu menyelesaikan permasalahan yang wujud. Impaknya adalah untuk menyediakan kanak-kanak dalam persekitaran kefahaman membaca menerusi pengaturan dan penjanaan minda demi memahami sesuatu idea tentang bacaan.

\section{Objektif Kajian}

Pelaksanaan kajian ini adalah untuk mengkaji kesan penggunaan bahan bacaan interaktif berasaskan laman web untuk kanak-kanak yang berumur lapan tahun terhadap pencapaian membaca. Objekti khusus pula adalah untuk:

i. Mengenal pasti skor min kefahaman membaca kanak-kanak yang berumur lapan tahun selepas menggunakan bahan bacaan interaktif berasaskan laman web dan bahan konvensional.

ii. Meninjau sama ada terdapat perbezaan yang signifikan dari segi kefahaman membaca selepas kanak-kanak yang berumur lapan tahun menggunakan bahan bacaan interaktif berasaskan laman web dan bahan konvensional.

\section{Soalan Kajian}

Dengan merujuk kepada kedua-dua objektif khusus di atas, soalan-soalan kajian digubal. Soalan-soalan kajian adalah seperti yang berikut:

i. Apakah skor min ujian pasca kefahaman membaca kanak-kanak yang berumur lapan tahun selepas menggunakan bahan bacaan interaktif berasaskan laman web dan konvensional?

ii. Adakah terdapat perbezaan yang signifikan dari segi kefahaman membaca selepas kanakkanak yang berumur lapan tahun menggunakan bahan bacaan interaktif berasaskan laman web dan bahan konvensional?

\section{Kepentingan Kajian}

Penggunaan atau pengaplikasian bahan sangat membantu proses pembacaan kanak-kanak yang bermasalah berasaskan kemahiran membaca, selain memberikan impak yang lebih teliti dan terancang. Hal ini demikian kerana bahan multimedia lazimnya menggabungkan teknik teks, grafik, audio dan animasi yang pelbagai untuk mewujudkan persekitaran yang baharu, di samping kaya dengan maklumat pemerolehan bahasa.

Elemen multimedia interaktif seperti video mampu membantu kanak-kanak dalam meningkatkan prestasi yang diharapkan sepanjang pelaksanaan proses membaca. Isi yang 
dimaklumkan terlebih dahulu sebelum sesi dijalankan akan menyebabkan kanak-kanak lebih bersedia dengan seluruh kandungan pelajaran dengan berpandukan tajuk tertentu. Dalam fasa perolehan ingatan kembali, kanak-kanak akan mampu mengingat atau membantuk kembali konsep-konsep atau gambaran isi-isi yang dipelajari.

Dari segi peranannya, teknologi maklumat dalam pendidikan perlu dilihat sebagai sesuatu yang menggerak dan merangsang proses pembacaan dengan lebih berkesan. Teknologi multimedia interaktif berasaskan laman web adalah salah satu teknologi baharu dalam bidang komputer yang terdapat daya saing kebolehan untuk kanak-kanak dalam menjadikan media pembacaan lebih lengkap, khususnya dalam proses membaca. Bahan multimedia interaktif berasaskan laman web yang digunakan dalam pendidikan dapat memberikan banyak kelebihan kepada guru dan kanak-kanak dalam mempertingkatkan kesan proses membaca.

Bahan multimedia interaktif berasaskan laman web yang digunakan dalam bacaan bagi Bahasa Melayu juga berkeupayaan untuk murid membaca ayat dengan lancar termasuk sebutan, intonasi, dan jeda yang betul. Hal ini demikian kerana penggunaan bahan multimedia interaktif berasaskan laman web merupakan suatu bentuk penekanan yang diberikan terhadap aspek kefahaman dan penaakulan pelbagai isi secara kreatif dan kritis.

Secara kesimpulannya, dapat dikatakan bahawa kepentingan kajian ini dapat memainkan peranan yang sangat penting dalam membantu proses kefahaman membaca bagi kanak-kanak. Dengan wujudnya bahan bacaan multimedia interaktif berasaskan laman web dalam sistem membaca, ini dapat membantu kanak-kanak untuk lebih mudah memahami dan menaakul setiap perkara yang diajarkan oleh guru, di samping menarik minat untuk mengikuti kesinambungan proses pembelajaran.

\section{Definisi Operasional}

\section{i. Bahan Bacaan Interaktif Berasaskan Laman Web}

Reka bentuk bahan bacaan interaktif berasaskan laman web ini adalah berasaskan integrasi dalam pembentukan atau gambaran atau mapping minda. Integrasi bersandarkan elemen asas multimedia tidak linear, iaitu teks, grafik, audio dan animasi (Wu, Hwang, Millard, Ke \& Huang, 2012).

Sebagai unsur tunggal dalam multimedia interaktif, dalam video terdapat keempat-empat elemen asas telah diintegrasikan. Bahan ini yang pada asalnya atau dalam bentuk sedia ada berupa buku digital sahaja.

Aspek operasi kefahaman melibatkan konstruk mapping minda; adaptasi, asimilasi, akomodasi dan ekuilibrasi. Proses untuk kefahaman bermula dengan membaca. Proses selanjutnya adalah dengan mencerapkan kandungan bacaan menerusi integrasi elemen multimedia interaktif berasaskan laman web (Rose, 2011; Chang, 2011). Proses kefahaman membaca turut dikombinasikan dengan variasi ilustrasi seperti grafik. Operasi ini adalah untuk menimbulkan rangsangan dan tindak balas kanak-kanak dalam menaakul isi-isi penting. Konteks integrasi yang dioperasikan adalah untuk penjanaan proses berfikir secara kreatif dan kritis oleh kanak-kanak (Wu, Hwang, Millard, Ke \& Huang, 2012). Struktur e-Bahan Interaktif 
Kefahaman Membaca Digital berasaskan laman web (e-BIKaM) adalah seperti yang dilihat dalam Rajah 1.

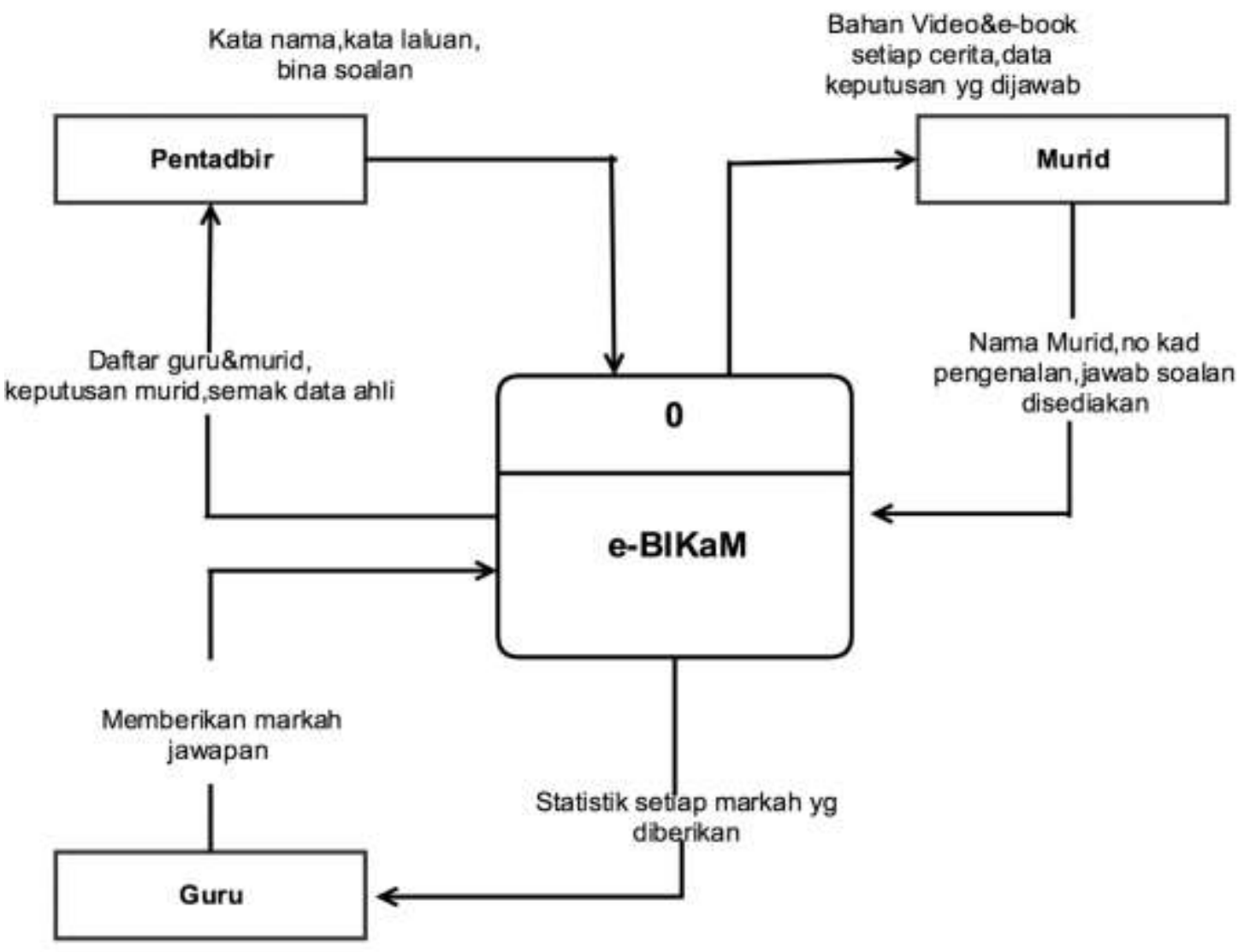

Rajah 1: Struktur bahan bacaan interaktif berasaskan laman web.

ii. Bahan Bacaan Konvensional

Bahan bacaan konvensional yang digunakan dalam kajian ini ialah buku teks. Bahan ini digunakan oleh guru dan murid secara manual dan tradisional untuk proses kefahaman membaca.

\section{iii. Kefahaman Membaca}

Kefahaman membaca dalam kajian ini adalah dengan berdasarkan ujian pra dan ujian pasca. Ujian pra diberikan sebelum murid didedahkan dengan penggunaan bahan berkaitan; bahan bacaan interaktif berasaskan laman web dan bahan bacaan konvensional. Ujian pasca pula diberikan selepas kanak-kanak didedahkan dengan penggunaan bahan tersebut. Kefahaman dioperasionalisasikan dalam bentuk skor. 


\section{TINJAUAN LITERATUR YANG BERKAITAN}

Masalah membaca dalam kalangan murid sekolah rendah dan menengah sering mendapat liputan umum. Masalah membaca telah menjejaskan usaha pihak sekolah untuk melahirkan murid yang berpengetahuan (Yahya Othman, 2004). Kerisauan tentang masalah ini bukan hanya pada ibu bapa dan guru. Berbagai-bagai usaha telah dilaksanakan di peringkat sekolah, daerah, negeri dan nasional. Satu usaha terbesar yang dilaksanakan adalah menerusi KSSR yang bermatlamatkan kecemerlangan pendidikan sekolah rendah, diikuti KSSM di peringkat sekolah menengah.

Keadaan ini amat membimbangkan apabila semakin ramai murid yang gagal membaca walaupun telah memasuki sekolah menengah. Sebagai usaha untuk memulihkan masalah membaca dalam kalangan murid sekolah rendah, Kementerian Pendidikan Malaysia telah memperkenalkan progran Kelas Intervensi Membaca. Dalam Malaysian Blueprint 2013-2025 pula, masalah membaca ini turut diberikan penekanan yang serius bermula di peringkat sekolah rendah (Kementerian Pendidikan Malaysia, 2013).

Dalam kajian ini, konteks masalah membaca cuba diatasi menerusi inovasi. Dari sudut makna, terdapat pelbagai pendapat tentang inovasi. Adenan Ayob et al. (2012) berpandangan bahawa inovasi ditafsirkan sebagai perkenalan sesuatu yang baharu dalam pendidikan. Clark dan Mayer (2012) pula memberikan maksud inovasi sebagai transformasi pengetahuan kepada produk dan proses baharu. Daripada definisi yang diberikan oleh Clark dan Mayer (2012), inovasi disimpulkan sebagai penggunaan ilmu pengetahuan yang dimiliki dalam menghasilkan sesuatu bahan yang baharu untuk digunakan. Di samping itu, Eitel dan Scheiter (2014) mengemukakan pendapat bahawa inovasi merupakan eksploitasi yang dihasilkan daripada sesuatu gagasan yang baharu. Inovasi juga boleh dirumuskan sebagai melakukan pemodifikasian terhadap bahan tertentu yang telah sedia ada untuk penghasilan produk yang baharu dan terkini yang menjurus ke arah pembentukan kemahiran membaca.

Inovasi merupakan kriteria pendidikan yang penting, selain ciri kreatif dalam diri seseorang guru. Hal ini disebabkan menerusi ciri-ciri inovasi, pembinaan, pembangunan atau kemajuan sesuatu bahan oleh guru boleh dilakukan untuk menghasilkan produk yang lebih canggih Clark dan Mayer (2012). Inovasi bermula dari peringkat perencanaan idea, dan berakhir dengan pelaksanaan idea dalam bentuk yang nyata atau zahir dengan mencerap pengetahuan tertentu. Pengaplikasian ilmu untuk penzahiran idea inovasi adalah dalam bentuk bahan, teknologi konkrit, teknologi abstrak seperti konsep, model, pendekatan, strategi, teknik dan paten (Clark \& Mayer, 2012).

Alat, iaitu komputer pada asalnya merupakan alat elektronik yang menyimpan maklumat pada cakera atau pita bermagnet. Kemudiannya, berlaku penganalisisan serta penghasilan maklumat apabila diperlukan (Fisher, 2014). Komputer digunakan secara meluas dalam pelbagai bidang utama seperti pendidikan. Komputer digunakan untuk memudahkan urusan seharian pengajaran dan pembelajaran. Sebagai contoh, dengan menggunakan komputer untuk mengakses internet, seseorang kanak-kanak mampu memperoleh maklumat yang dikehendaki hanya dalam beberapa saat. Di samping itu, menerusi komputer, kanak-kanak boleh terus berkomunikasi secara maya. Hal ini menunjukkan bahawa komputer boleh membantu kanakkanak dalam komunikasi digital dan maya. Dalam bidang pendidikan, komputer menjadi alat 
pengajaran dan pembelajaran yang amat diperlukan dalam inovasi pendidikan (Hashemain, Jam \& Narki, 2014).

Golongan mentalis berpendapat bahawa kanak-kanak dikatakan sebagai memiliki kecekapan dan prestasi semula jadi. Kecekapan membaca adalah dalam rumus-rumus atau undang-undang pembacaan yang ada dalam mental, terutamanya pengetahuan tentang konsep yang meliputi isi, bahasa dan keseluruhan kefahaman. Prestasi pula ialah ukuran kefahaman dengan berpandukan sesuatu penilaian tentang pengetahuan (James McMillan, 2010). Dalam erti kata lain, prestasi ialah hasil membaca mengikut pengetahuan dan kecekapan kanak-kanak dalam isi, bahasa dan keseluruhan kefahaman. Dalam usaha kanak-kanak menghasilkan ayatayat dalam pembacaan, kecekapan merupakan kriteria utama dalam mengukur output terakhir.

Fahaman mentalis menekankan bahawa wujud hubungan yang erat antara bacaan dengan pemikiran (Heidarifard, 2014). Dalam aspek ini, Piaget menyebut bahawa makna ayat adalah diutamakan (Heidarifard, 2014). Oleh itu, apabila seseorang membaca, pemikiran perlu berfokus ke arah penyebutan ayat-ayat yang gramatis dan bermakna.

Teori golongan mentalis juga menggarab idea bahawa pengetahuan tatabahasa diterapkan dalam membaca secara sedar kepada kanak-kanak, sama ada secara induktif mahupun deduktif kerana daripada pengetahuan tersebut, wujud keupayaan membentuk ayat-ayat yang gramatis dan bermakna (Kalhor \& Shakibaei, 2012). Rumus-rumus yang dipelajari perlu disertakan huraian yang mantap. Prinsip ini menjadi pegangan utama golongan mentalis kerana bagi mereka, pembacaan dilalui menerusi proses pemikiran. Dalam pembacaan menerusi komputer, pengetahuan kanak-kanak dari segi isi, bahasa dan pengolahan perlu lengkap untuk menggalakkan cara berfikir secara kreatif dan analitis. Sehubungan dengan itu, proses pembelajaran pembacaan perlu dapat merangsang kanak-kanak menggunakan kemampuan kreatif dan analitis untuk merumus atau menguji hipotesis (Kalhor \& Shakibaei). Dalam proses pembacaan, guru bertindak sebagai pakar rujuk untuk menentukan sama ada terdapat pembentukan ataupun percubaan hipotesis yang betul oleh kanak-kanak.

Pandangan yang dikemukakan oleh Nickolarazi dan Vekiri (2012) pula menyebut bahawa pembacaan yang tepat berasaskan teknologi membolehkan kanak-kanak membaca secara mantap, selain membuat analisis. Kebolehan semula jadi ini datangnya secara intituatif atau diberikan istilah pengukur dalam penerbitan bahasa (Nickolarazi dan Vekiri). Dalam hal ini, pembacaan perlu berpandukan cara seseorang kanak-kanak memperoleh asas sebutan suku kata yang kukuh untuk kefahaman. Usaha ini harus dimulakan daripada pengalaman yang terdekat dan kemudian bergerak kepada pengalaman yang lebih luas (Kalhor \& Shakibaei, 2012). Jelasnya, segala aktiviti harus bergerak daripada pengetahuan asas murid.

\section{METODOLOGI}

\section{Kaedah Kajian}

Dalam penyelidikan ini, kaedah kuasi eksperimen digunakan. Kaedah ini diasaskan kepada reka bentuk kajian kuantitatif. 
Reka bentuk ujian pra dan ujian pasca yang digunakan dalam kajian ini adalah diaplikasikan daripada pendapat Fraenkal dan Wallen (2009). Reka bentuk kajian adalah dalam Jadual 1.

Jadual 1: Reka bentuk kajian kuasi eksperimen.

\begin{tabular}{lllc}
\hline Kumpulan & Ujian Pra & Penggunaan Bahan & Ujian Pasca \\
\hline Rawatan O1 & X1 & O2 \\
& Bahan Interaktif & \\
Kawalan O3 & $\begin{array}{l}\text { X2 } \\
\text { Bahan Konvensional }\end{array}$ & O4 \\
\hline
\end{tabular}

Petunjuk:

O1 dan $\mathrm{O} 3=$ Ujian Pra

$\mathrm{X} 1=$ Bahan Bacaan Interaktif

$\mathrm{O} 2$ dan $\mathrm{O} 4=$ Ujian Pasca

$\mathrm{X} 2$ = Bahan Bacaan Konvensional

Pemilihan sampel dalam kajian ini adalah secara rawak yang dilakukan dalam kalangan kanakkanak sekolah rendah yang berumur lapan tahun. Ujian pra yang mengukur kefahaman membaca kanak-kanak digambarkan oleh $\mathrm{O} 1$ dan $\mathrm{O} 3$, manakala ujian pasca digambarkan oleh O2 dan O4. Subskrip X1 (bahan bacaan interaktif berasaskan laman web) dan X2 (bahan bacaan konvensional) merujuk kepada bahan ukuran yang berbeza. Oleh itu, ujian pra dan pasca merupakan instrumen kajian yang mengukur skor pencapaian kefahaman membaca kanak-kanak yang berada dalam lingkungan umur tersebut.

\section{Sampel Kajian}

Bagi kajian ini, sampel adalah terdiri daripada 30 orang kanak-kanak sekolah rendah kebangsaan yang berumur lapan tahun, masing-masing daripada sebuah sekolah di dalam negeri Perak dan Selangor. Pemilihan sekolah dibuat dengan berdasarkan: (i) Pencapaian kanak-kanak yang sederhana dalam Bahasa Melayu bagi ujian Mei, 2016; (ii) Kanak-kanak telah didedahkan dengan penggunaan bahan bacaan interaktif berasaskan laman web; (iii) Sekolah memiliki fasiliti makmal komputer dan wifi; dan (iv) Terdapat guru Bahasa Melayu yang berkemahiran dalam pengajaran berbantukan komputer.

Setiap sekolah di dalam negeri yang terlibat telah dipilih secara rawak, iaitu 15 orang untuk kumpulan yang didedahkan dengan bahan bacaan intraktif berasaskan laman web, manakala 15 orang untuk kumpulan yang didedahkan dengan bahan konvensional. Pemilihan saiz sampel ini adalah dengan berpandukan pandangan sarjana-sarjana penyelidikan. Menurut James McMillan (2010), saiz minimum sampel yang sesuai dalam kajian kuasi eksperimen ialah 30 orang.

\section{Instrumen Kajian}

\section{Ujian Pra dan Ujian Pasca}

Instrumen bagi penyelidikan ini ialah satu set ujian pra dan satu set ujian pasca. Tiga orang guru Bahasa Melayu dilantik oleh pengkaji sebagai panel penggubal soalan ujian pra dan ujian pasca. 
Ketiga-tiga orang panel penggubal soalan berkenaan turut menentukan aras soalan ujian pra dan pasca adalah sama. Bagi kajian ini, penggubalan soalan ujian pra dan pasca dirujuk kepada Sukatan Pelajaran Bahasa Melayu Tahun Dua.

\section{Kesahan}

Kesahan instrumen berdasarkan kandungan ujian pra dan pasca dilakukan dalam kajian ini. Kesahan bermaksud kesesuaian intepretasi yang dilakukan dengan berpandukan markah ujian yang dibuktikan daripada pengukuran sesuatu pencapaian (James McMillan, 2010). Kesahan kandungan sesuatu alat kajian merujuk kepada sejauh mana alat itu mengumpul data yang merangkumi kandungan sesuatu bidang yang dikaji (James McMillan).

Dalam mencapai tujuan penyemakan kesahan kandungan ujian pra dan pasca bagi kajian ini, tiga orang guru dilantik sebagai panel. Panel penyemak kesahan kandungan ujian pra dan pasca pula terdiri daripada seorang guru Bahasa Melayu Sekolah Kebangsaan Rawang, Selangor. Guru ini mempunyai pengalaman mengajar Bahasa Melayu sekolah rendah selama 10 tahun, selain pernah menjalani kursus pembinaan item ujian.

Kesahan bahan bacaan interaktif telah dilakukan oleh pakar. Pakar tersebut adalah seorang Guru Bahasa Melayu yang berkepakaran dalam pengajaran berasaskan teknologi maklumat dan komunikasi selama 10 tahun.

\section{Kebolehpercayaan Instrumen}

Dalam menentukan kebolehpercayaan ujian pra dan pasca, pengkaji telah menjalankan kajian rintis di Sekolah Kebangsaan Seksyen 9, Shah Alam, Selangor. Seramai 15 orang murid telah terlibat dalam dua sesi ujian, iaitu ujian pra dan pasca. Seorang guru Bahasa Melayu dari sekolah yang sama telah dilantik untuk mengawasi ujian-ujian berkenaan. Dalam sesi ujian pra, 15 orang murid terlibat. Ujian pra dan pasca diadakan pada hari yang berasingan, iaitu berselang satu minggu. Ujian pra dan pasca diadakan dalam masa satu jam. Lihat Jadual 2.

Jadual 2: Kebolehpercayaan ujian pra dan pasca.

\begin{tabular}{|c|c|}
\hline Ujian & Nilai Pekali Cronbach's Alpha \\
\hline Pra & 0.79 \\
\hline Pasca & 0.81 \\
\hline
\end{tabular}

Dalam Jadual 2 tersebut, nilai Pekali Cronbach's Alpha ujian pra ialah 0.79. Nilai pekali ujian pasca pula ialah 0.81. Ini memaparkan bahawa ujian pra dan pasca mempunyai kebolehpercayaan yang tinggi. Menurut James McMillan (2010), semakin tinggi nilai pekali iaitu menghampiri 1, maka semakin baik sesuatu instrumen.

\section{Prosedur Pengumpulan Data}

Proses pengumpulan data ujian pra mula dilakukan pada bulan Ogos 2016. Pengumpulan data ujian pasca pula dilakukan pada bulan September 2016. Sila lihat Jadual 3 dan Jadual 4. 
Jadual 3: Pengumpulan data ujian pra.

\begin{tabular}{|l|l|l|}
\hline Bil. & \multicolumn{1}{|c|}{ Aktiviti } & \multicolumn{1}{|c|}{ Tempoh / Masa } \\
\hline i. & Lantik guru pembantu untuk mengawasi ujian pra dan pasca. & Ogos 2016 \\
\hline ii. & Sampaikan taklimat ujian kepada guru pembantu. & $\begin{array}{l}\text { Ogos 2016 / 10 } \\
\text { minit }\end{array}$ \\
\hline iii. & Guru pembantu menyampaikan taklimat ujian pra. & $\begin{array}{l}\text { Ogos 2016 / 5 } \\
\text { minit }\end{array}$ \\
\hline iv. & Murid-murid menjawab soalan ujian pra. & Ogos 2016 / 1 jam \\
\hline v. & Guru pembantu memungut skrip jawapan. & $\begin{array}{l}\text { Ogos 2016 / 5 } \\
\text { minit }\end{array}$ \\
\hline vi. & $\begin{array}{l}\text { Pengkaji melantik seorang guru Bahasa Melayu untuk memeriksa } \\
\text { skrip jawapan ujian pra. }\end{array}$ & Ogos 2016 / 1 hari \\
\hline
\end{tabular}

Jadual 4: Pengumpulan data ujian pasca.

\begin{tabular}{|c|l|l|}
\hline Bil. & \multicolumn{1}{|c|}{ Aktiviti } & \multicolumn{1}{|c|}{ Tempoh / Masa } \\
\hline i. & Lantik guru pembantu untuk mengawasi ujian pra dan pasca. & Sep. 2016 \\
\hline ii. & Sampaikan taklimat ujian kepada guru pembantu. & $\begin{array}{l}\text { Sep. 2016 / 10 } \\
\text { minit }\end{array}$ \\
\hline iii. & Guru pembantu menyampaikan taklimat ujian pra. & $\begin{array}{l}\text { Sep. 2016 / 5 } \\
\text { minit }\end{array}$ \\
\hline iv. & Murid-murid menjawab soalan ujian pra. & Sep. 2016 / 1 jam \\
\hline v. & Guru pembantu memungut skrip jawapan. & $\begin{array}{l}\text { Sep. 2016 / 5 } \\
\text { minit }\end{array}$ \\
\hline vi. & $\begin{array}{l}\text { Pengkaji melantik seorang guru Bahasa Melayu untuk memeriksa } \\
\text { skrip jawapan ujian pra. }\end{array}$ & Sep. 2016 / 1 hari \\
\hline
\end{tabular}

\section{Penganalisisan Data}

Dalam kajian yang berupa kuasi eksperimen, data kajian dikumpulkan daripada ujian pra dan ujian pasca. Setelah semua instrumen diperoleh, proses pengekodan dilakukan untuk memudahkan aktiviti kemasukan data dalam program SPSS. Proses penganalisisan data melibatkan dua jenis statistik, iaitu statistik deskriptif dan statistik inferensi. Statistik deskriptif yang digunakan ialah pelaporan min dan sisihan piawai. Statistik inferensi pula digunakan untuk pelaporan tinjauan perbezaan skor min menerusi ANCOVA. Sila rujuk Jadual 5.

Jadual 5: Analisis data.

\begin{tabular}{|l|l|l|}
\hline Bil. & \multicolumn{1}{|c|}{ Soalan Kajian } & \multicolumn{1}{|c|}{ Statistik } \\
\hline i. & $\begin{array}{l}\text { Apakah skor min ujian pasca kefahaman } \\
\text { membaca kanak-kanak yang berumur lapan tahun } \\
\text { selepas menggunakan bahan bacaan interaktif dan } \\
\text { bahan konvensional? }\end{array}$ & $\begin{array}{l}\text { Deskriptif: } \\
\text { Min dan Sisihan Piawai }\end{array}$ \\
\hline
\end{tabular}




\begin{tabular}{|l|l|l|}
\hline ii. & $\begin{array}{l}\text { Adakah terdapat perbezaan yang signifikan dari segi } \\
\text { kefahaman membaca selepas kanak-kanak yang berumur } \\
\text { lapan tahun menggunakan bahan bacaan interaktif dan bahan } \\
\text { konvensional? }\end{array}$ & $\begin{array}{l}\text { Inferensi: } \\
\text { ANCOVA }\end{array}$ \\
\hline
\end{tabular}

\section{DAPATAN KAJIAN}

\section{Demografi Responden}

Jadual 6 menunjukkan demografi responden. Paparan jadual adalah berkaitan dengan kumpulan kajian, bahan bacaan, dan negeri yang terlibat dalam penyelidikan, termasuk bilangan serta peratus kanak-kanak.

Jadual 6: Demografi responden.

\begin{tabular}{lllc}
\hline Kumpulan & Bahan & Negeri / Bilangan Kanak-Kanak (\%) \\
\hline \multirow{2}{*}{ Eksperimen } & Interaktif & Perak: & $15(25 \%)$ \\
& & Selangor: & $15(25 \%)$ \\
Kawalan & Konvensional & Perak: & $15(25 \%)$ \\
& & Selangor: & $15(25 \%)$ \\
\hline
\end{tabular}

Jumlah

$60(100 \%)$

Daripada paparan Jadual 6 tersebut, kajian ini membabitkan dua kumpulan. Kumpulan eksperimen menggunakan bahan bacaan interaktif berasaskan laman web. Kumpulan kawalan pula menggunakan bahan bacaan konvensional. Kumpulan eksperimen ialah 15 orang, masingmasing bagi negeri Perak dan Selangor. Kumpulan kawalan juga ialah 15 orang, masing-masing bagi negeri Perak dan Selangor. Keseluruhan kanak-kanak yang terlibat dalam kajian ini ialah 60 orang.

Apakah skor min ujian pasca kefahaman membaca kanak-kanak yang berumur lapan tahun selepas menggunakan bahan bacaan interaktif berasaskan laman web dan konvensional?

Jadual 7 memaparkan min dan sisihan piawai yang dianalisis bagi sebuah sekolah rendah di negeri Perak. Min dan sisihan piawai dipersembahkan seperti yang berikut: 
Jadual 7: Min dan sisihan piawai bagi sebuah sekolah rendah di negeri Perak.

\begin{tabular}{lcc}
\hline Bahan Bacaan & Min & Sisihan Piawai \\
\hline Konvensional & 67.1 & 10.1 \\
Interaktif & 83.7 & 7.9 \\
\hline
\end{tabular}

Dalam Jadual 7, min bahan bacaan konvensional ialah 67.1 $(\mathrm{SP}=10.1)$. Min bahan bacaan interaktif berasaskan laman web pula ialah $83.7(\mathrm{SP}=7.9)$.

Dalam Jadual 8 pula ditunjukkan min dan sisihan piawai yang dianalisis bagi sebuah sekolah rendah di negeri Selangor. Min dan sisihan piawai diperlihatkan dalam jadual berkenaan.

Jadual 8: Min dan sisihan piawai bagi sebuah sekolah rendah di negeri Selangor.

\begin{tabular}{lcc}
\hline Bahan Bacaan & Min & Sisihan Piawai \\
\hline Konvensional & 66.3 & 11.8 \\
Interaktif & 83.4 & 8.6 \\
\hline
\end{tabular}

Dalam Jadual 8 di atas, min bahan bacaan konvensional ialah 66.3 (SP = 11.8). Min bahan bacaan interaktif berasaskan laman web pula ialah $83.4(\mathrm{SP}=8.6)$.

Adakah terdapat perbezaan yang signifikan dari segi kefahaman membaca selepas kanakkanak yang berumur lapan tahun menggunakan bahan bacaan interaktif berasaskan laman web dan konvensional?

Jadual 9 mempersembahkan analisis kovarian. Analisis berkenaan adalah bagi sebuah sekolah rendah di dalam negeri Perak.

Jadual 9: Analisis kovarian bagi sebuah sekolah rendah di dalam negeri Perak.

\begin{tabular}{lllllll}
\hline Sumber & $\begin{array}{l}\text { Jumlah Kuasa } \\
\text { Dua }\end{array}$ & $\begin{array}{l}\text { Darjah } \\
\text { Kebebasan }\end{array}$ & $\begin{array}{l}\text { Min Kuasa } \\
\text { Dua }\end{array}$ & F & Sig. \\
\hline Ujian Pra & 221.6 & 1 & 18.9 & 177.3 & .000 \\
Bahan & 179.7 & 1 & 16.2 & 13.2 & .001 \\
Kesilapan & 341.1 & 27 & & & \\
Jumlah & 19335.0 & 30 & & & \\
Jumlah & & & & & \\
Dibetulkan & 5517.88 & 29 & & & & \\
& & & & & & \\
\hline
\end{tabular}

Paras Signifikan $<0.05$ 
Dalam Jadual 9 dipaparkan nilai $F(1,27)=13.2$, dengan paras signifikan adalah $<0.05$. Ini menunjukkan bahawa terdapat perbezaan yang signifikan dari segi kefahaman membaca antara penggunaan bahan interaktif berasaskan laman web dengan penggunaan bahan konvensional apabila ujian pra adalah dikawal secara statistik atau kovariat.

Jadual 10 pula mempersembahkan analisis kovarian. Analisis tersebut adalah bagi sebuah sekolah rendah di dalam negeri Selangor.

Jadual 10: Analisis kovarian bagi sebuah sekolah rendah di dalam negeri Selangor.

\begin{tabular}{llcllll} 
Sumber & $\begin{array}{l}\text { Jumlah Kuasa } \\
\text { Dua }\end{array}$ & $\begin{array}{l}\text { Darjah } \\
\text { Kebebasan }\end{array}$ & $\begin{array}{l}\text { Min Kuasa } \\
\text { Dua }\end{array}$ & F & Sig. \\
\hline Ujian Pra & 2188.6 & 1 & 213.1 & 177.0 & .000 \\
Bahan & 79.8 & 1 & 77.7 & 6.3 & .002 \\
Kesilapan & 333.7 & 27 & & & \\
Jumlah & 181004.0 & 30 & & & \\
Jumlah & & & & & \\
Dibetulkan & 5164.5 & 29 & &
\end{tabular}

Paras Signifikan $<0.05$

Jadual 10 menunjukkan nilai $\mathrm{F}(1,27)=6.3$, dengan paras signifikan adalah $<0.05$. Ini menunjukkan bahawa terdapat perbezaan yang signifikan dari segi kefahaman membaca antara penggunaan bahan interaktif berasaskan laman web dengan penggunaan bahan konvensional apabila ujian pra dikawal secara statistik atau kovariat.

\section{PERBINCANGAN}

Dapatan di atas dapat dirumuskan bahawa terdapat perbezaan yang signifikan dari segi kefahaman membaca antara penggunaan bahan interaktif berasaskan laman web dengan penggunaan bahan konvensional apabila ujian pra adalah dikawal secara statistik atau kovariat. Dapatan ini turut menyokong hasil penyelidikan yang lepas tentang kajian kefahaman membaca dalam dengan berasaskan bahan multimedia (Nickolarazi \& Vekiri, 2012).

Penggunaan bahan bacaan interaktif berupaya membantu kanak-kanak untuk meningkatkan hasil bacaan boleh dikaitkan dengan sifat-sifat utama penggunaan dan pengaplikasiannya. Antaranya, pembacaan dengan menggunakan bahan bacaan yang mempunyai sifat interaktif, pelbagai media, akses dalam talian, penerbitan elektronik dan penyebaran maklumat yang global. Sebagai contoh, dengan adanya ciri penyebaran maklumat, kanak-kanak mampu 
meningkatkan pengetahuan tentang isi bacaan, selain mendorong meningkatkan kefahaman dalam bacaan (Singh \& Mishra, 2016).

Hasil kajian ini juga adalah seiring dengan pendapat Piaget, iaitu pencapaian kanak-kanak dalam membaca adalah baik apabila senario pembelajaran dan cara penggunaan bahan yang mesra pengguna yang lengkap mampu mencetuskan peluang untuk menambahkan ilmu pengetahuan yang luas (Singh \& Mishra, 2013). Dapatan kajian ini turut menyokong pendapat Saeedi, Saif, Asadzadah \& Qavam (2013) yang berpendapat bahawa penggunaan bahan multimedia interaktif dalam membaca menyediakan persekitaran yang bernilai global yang menggiatkan pemikiran kreatif kanak-kanak ke arah menghasilkan kefahaman bacaan yang bertahap cemerlang. Saeedi, Saif, Asadzadah \& Qavam menambah bahawa faktor mesra penggunaan bahan multimedia interaktif dianggap sesuatu yang memberangsangkan pembelajaran membaca. Menurut beliau juga, komputer berfungsi membantu kanak-kanak untuk mengaplikasikan isi bacaan secara tepat, selain dapat mengakses sumber pengetahuan yang global untuk disesuaikan dengan kandungan bacaan (Singh \& Mishra, 2016). Beliau juga secara ringkas mentafsirkan kepintaran dalam memperoleh bahasa menerusi penggunaan bahan multimedia adalah untuk memantapkan usaha menimba ilmu pengetahuan bacaan, mengenal pasti ketepatan isi, selain menilai kesahan maklumat yang diperoleh untuk diselarikan dengan sesuatu topik bacaan.

Aspek kefahaman kanak-kanak dalam membaca juga berkait dengan faktor variasi dalam aktiviti maya. Pernyataan ini didapati selari dengan pendapat Phantharakphong dan Pothitha (2013) bahawa pengetahuan luas yang diperoleh kanak-kanak di dalam kelas berupaya membantu usaha mereka dalam aktiviti sampingan yang mempunyai unsur permainan berasaskan akses video, seperti menaakul isi-isi bacaan. Langkah tersebut juga didapati berjaya membina dan memantapkan minda kanak-kanak tentang isi bacaan yang merupakan salah satu komponen penting dalam teori Piaget. Kenyataan ini juga adalah bertepatan dengan teori pembelajaran bacaaan, iaitu pendedahan dalam pengetahuan tentang input bacaan yang spesifik dapat membantu kanak-kanak menghasilkan kefahaman bacaan yang terbaik (Singh \& Mishra, 2016).

Aspek kefahaman membaca kanak-kanak juga meningkat setelah menggunakan bahan multimedia turut berkait rapat dengan organisasi paparan antaramuka bahan dalam pembacaan (Nickolarazi \& Vekiri, 2012). Organisasi ini dapat mencorakkan kemahiran kanak-kanak untuk menyerap isi yang luas berasaskan integrasi elemen multimedia, selain penerangan tentang struktur isi (Singh \& Mishra). Dengan bantuan teknologi maklumat misalnya, kanak-kanak dapat mencerap bahan bacaan tertentu untuk disesuaikan dengan topik bacaan. Dengan bantuan integrasi multimedia pula, kanak-kanak dapat dibimbing untuk menggunakan integrasi isi secara betul dan tepat menerusi pencerapan kefahaman yang konkrit dan cerakin.

Hasil kajian ini juga berkaitan dengan keputusan Chang (2011) yang membicarakan bahawa usaha kanak-kanak untuk terus membaca dirangsang oleh integrasi elemen multimedia dan kandungan pedagogi, selainj disokong oleh akses maklumat tambahan dalam sistem. Dengan adanya panduan untuk menggunakan penaakulan isi penting bacaan, kanak-kanak dapat menampilkan variasi kefahaman (Nickolarazi \& Vekiri, 2012). Tatacara ini dianggap penting untuk menghasilkan kefahaman bacaan yang cemerlang dari sudut kefahaman. 
Kewujudan peningkatan dalam kefahaman bacaan juga berkait rapat dengan kemahiran daya berfikir kanak-kanak dalam menampilkan idea yang tepat, padat dan bernas. Menurut Chang (2011), peningkatan daya saing berfikir kanak-kanak dalam pembacaan adalah dirangsang oleh motivasi intrinsik ketika menggunakan bahan multimedia yang interaktif.

Produk berasaskan bahan ini juga adalah sesuai digunakan oleh kanak-kanak dengan berpandukan faktor rangsangan untuk berusaha lebih gigih dalam menjadikan kefahaman bacaan berkualiti menerusi semangat koperatif, berintuitif, selain dibantu oleh persekitaran teknologi maklumat yang berasaskan digital dan maya (Chang, 2011). Pendapat ini ada kewajarannya bahawa suasana membaca dalam konteks koperatif yang bersaing akan meningkatkan kefahaman membaca ke arah yang berkualiti tinggi, selain berupaya meningkatkan kemampuan untuk berfikir secara tepat, konkrit dan logik (Nickolarazi \& Vekiri, 2012).

\section{IMPLIKASI KAJIAN}

Hasil kajian ini turut memberi impilkasi terhadap proses pengajaran dan pembelajaran membaca. Implikasi daripada dapatan kajian ini menunjukkan bahawa bahan bacaan multimedia interaktif berasaskan laman web wajar digunakan di dalam kelas secara menyeluruh. Penggunaan bahan interaktif ini didapati memanfaatkan kanak-kanak dalam kefahaman kerana dapat menjimatkan masa dalam aktiviti membaca. Kanak-kanak juga tidak perlu mengulangi pembacaan jika berlaku kesalahan isi dan sebagainya.

Bahan ini juga dapat memudahkan kanak-kanak mengakses maklumat tentang isi bacaan daripada integrasi pelbagai elemen multimedia. Langkah ini didapati menggalakkan tumpuan murid untuk membaca dengan lebih jelas dan bernas. Dengan adanya bantuan integrasi, kanakkanak dapat membuat rujukan isi, bahasa dan pengolahan secara lebih khusus. Langkah ini juga dapat memberikan alternatif kepada kanak-kanak untuk melakukan pencarian maklumat yang lebih mendalam tentang isi-isi bacaan berdasarkan sesuatu topik. Langkah ini juga wajar dipraktikkan secara meluas di dalam kelas kerana ini didapati sesuai untuk mengurangkan bebanan guru dalam persediaan pengajaran. Penyediaan panduan yang seragam tentang penggunaan bahan yang berdasarkan panduan khas juga adalah langkah terbaik untuk memastikan penggunaannya bermanfaat kepada kanak-kanak dalam membaca.

\section{CADANGAN}

Hasil perbincangan tersebut di atas, beberapa cadangan telah dikenal pasti dan dinyatakan dalam kajian ini. Hasil kajian ini berasaskan dapatan menunjukkan bahawa penggunaan bahan bacaan interaktif berasaskan laman web adalah berkesan kepada kefahaman membaca kanak-kanak berumur lapan tahun. Ini secara langsung memberikan manfaat kepada usaha pemupukan keupayaan dalam kemahiran membaca.

Justeru, pihak berwajib wajar mengkaji keperluan untuk melengkapkan kelas dengan komputer, termasuk membekalkan kemudahan wifi supaya penggunaan bahan bacaan interaktif berasaskan laman web dalam membaca adalah menyeluruh, licin dan lancar. Tujuan kelas dilengkapkan dengan peralatan komputer, perisian dan internet adalah untuk memberikan kemudahan kepada kanak-kanak supaya memperoleh faedah yang maksimum daripada arus 
pembelajaran berasaskan teknologi maklumat. Kelengkapan infrastruktur juga amat penting untuk memastikan kanak-kanak sentiasa berminat terhadap pembelajaran digital dan maya. Cadangan ini juga adalah dengan berpandukan kadar kejayaan kanak-kanak yang terlibat dalam penggunaan bahan bacaan interaktif berasaskan laman web. Jika lebih banyak kanak-kanak terlibat dengan penggunaan bahan bacaan interaktif, kadar kejayaan akan lebih meningkat.

Daripada usaha guru memastikan bidang komputer dan teknologi maklumat bermanfaat kepada kanak-kanak dalam kefahaman membaca, kajian juga perlu dilakukan terhadap aspek penulisan. Tujuannya untuk memantapkan penggabungjalinan dalam semua aspek kemahiran berbahasa. Cadangan kajian juga perlu menjurus kepada usaha mempelbagaikan pembangunan bahan membaca. Fokus kajian wajar dalam membaca secara kritis. Langkah sedemikian dapat mewujudkan variasi bahan bantu pembelajaran bagi kanak-kanak dalam mata pelajaran Bahasa Melayu.

Daripada aturan langkah untuk memperluas penggunaan bahan bacaan interaktif berasaskan laman web, kepakaran guru dalam bidang teknologi maklumat adalah amat perlu. Kewibawaan guru untuk membimbing kanak-kanak dalam kefahaman membaca perlu seiring dengan kepakaran khusus tentang teknologi maklumat. Atas kesedaran ini, pihak KPM perlu membuka ruang dan peluang kepada guru sekolah rendah supaya dapat menambahkan pengetahuan dan kepakaran dalam bidang komputer dan teknologi maklumat menerusi kursus-kursus yang bersifat intensif.

Pelbagai pihak terutamanya pengurusan sekolah memang tidak dapat menafikan bahawa tugas setiap guru Bahasa Melayu di sekolah adalah begitu banyak dan kompleks, selain perlu merancang pengajaran dan menyediakan bahan bantu membaca. Masa akan dapat dijimatkan jika guru bijak mengatur usaha dalam merancang penyediaan dan penggunaan bahan untuk membaca.

\section{PENUTUP}

Sebagai kemudahan untuk guru dinamika dalam pengajaran dan pembelajaran digital dan maya, pihak pengurusan sekolah perlu menggembleng penglibatan guru ke arah pembinaan atau pembangunan atau pemodifikasian bahan bantu pengajaran dan pembelajaran yang interaktif dengan berasaskan laman web, selain bersesuaian dengan sukatan pelajaran berkaitan. Langkah ini dapat mewujudkan variasi dalam penggunaan bahan bacaan interaktif supaya kanak-kanak terus berminat untuk belajar sehingga memperoleh kefahaman yang terbaik dalam membaca.

Sudah tiba masanya pihak berkaitan menggubal sukatan pembelajaran elektronik yang berkonsepkan digital dan maya yang mempunyai pendekatan mesra kanak-kanak. Bahan multimedia interaktif berasaskan laman web perlu dijadikan keperluan utama dalam semua program dan aktiviti membaca yang bermula dari peringkat pendidikan awal kanak-kanak supaya asasnya berkesinambungan kepada peringkat yang lebih tinggi. 


\section{RUJUKAN}

Adenan Ayob et al. (2012). Using Multimedia for Teaching Malay Language. Tanjung Malim, Perak: Emeritus Publications.

Chang, S. (2011). Concept mapping to improve learning. English Language Teaching, 4 (2) 24-250.

Clark, R. C., \& Mayer, R. E. (2012). E-Learning And The Science Of Instruction: Proven Guidelines For Consumers And Designers Of Multimedia Learning. John Wiley \& Sons.

Dzulkifli, M. A., \& Mustafar, M. F. (2013). The influence of color on memory performance: A review. The Malaysian Journal of Medical Sciences: MJMS, 20(2), 3.

Eitel, A., \& Scheiter, K. (2014). Picture or Text First? Explaining Sequence Effects when Learning with Pictures and Text. Educational Psychology Review, 1-28.

Fisher, K. (2014). SemNet Software as an Assessment Tool. Academic Press, Burlington.

Fraenkel, J. R., \& Wallen, N. E. (2009). How to design and evaluate research in education (7th ed). New York. McGraw-hill.

Hashemain, M., Jam, B., \& Narki, S. (2014). Improving comprehension of Iranian high school students via graphic organizers. International Journal of Educational Investigation, 1 (1), 93-110.

Heidarifard, M. (2014). The effect of graphic organizers on L2 learners' reading comprehension. Journal of American Science, 10 (3), 62-71.

James H. McMillan. (2010). Understanding and Evaluating Educational Research, 4th Edition. Virginia Commonwealth University

Kalhor, M. \& Shakibaei, G. (2012). Teaching reading comprehension. Life Science Journal, 9(4), 725731.

Kementerian Pendidikan Malaysia. (2013). Malaysia Education Blueprint 2013-2025. Putrajaya: Kementerian Pendidikan Malaysia.

Nickolarazi, M., \& Vekiri. (2012). The design of software to enhance the reading comprehension of deaf children: An integration of multiple theoretical perspectives. Education and Information Technologies, 17 (2), 167-185. DOI: 10.1007/s106-011-9152-1.

Phantharakphong, P., \& Pothitha, S. (2013). Development of reading comprehension by using concept maps. Social and Behavioral Sciences, 116 (5), 497-501.

Rose, E. (2011). The phenomenology of on-screen reading: University students' lived experience of digitized text. British Journal of Educational Technology, 42(3), 515-526.

Saeedi, A., Saif, A., Asadzadah, H., \& Qavam, S. (2013). Comparing effectiveness of methods of presentation and providing concept maps on reading comprehension. European Journal of Experimental Biology, 3 (2), 545-50.

Singh, S., \& Mishra, S. A. (2013). Study About Role of Multimedia in Early Childhood Education. International Journal of Humanities and Ssocial Science Invention, 2 (6), 80-85.

Singh, S., \& Mishra, S. (2016). Positive influence of the Multimedia in Primary Education. The International Journal of Indian Psychology 2016, 3(2), 179-183.

Suleimani, H., \& Nahizadah, F. (2012). The effect of learners constructed, fill in the map concept map technique, and summarizing strategy on Iranian pre-university students reading comprehension. English Language Teaching Journal, 5, 78-87.

Wu, P., Hwang G., Millard, M. Ke, H. \& Huang, Y. (2012). An innovative concept map approach for improving students' learning performance with an instant feedback mechanism. British Journal of Educational Technology, 43(2), 217-232.

Yahya Othman. (2004). Mengajar Membaca: Teori dan Aplikasi. Bentong: PTS Publications \& Distributors Sdn. Bhd. 